
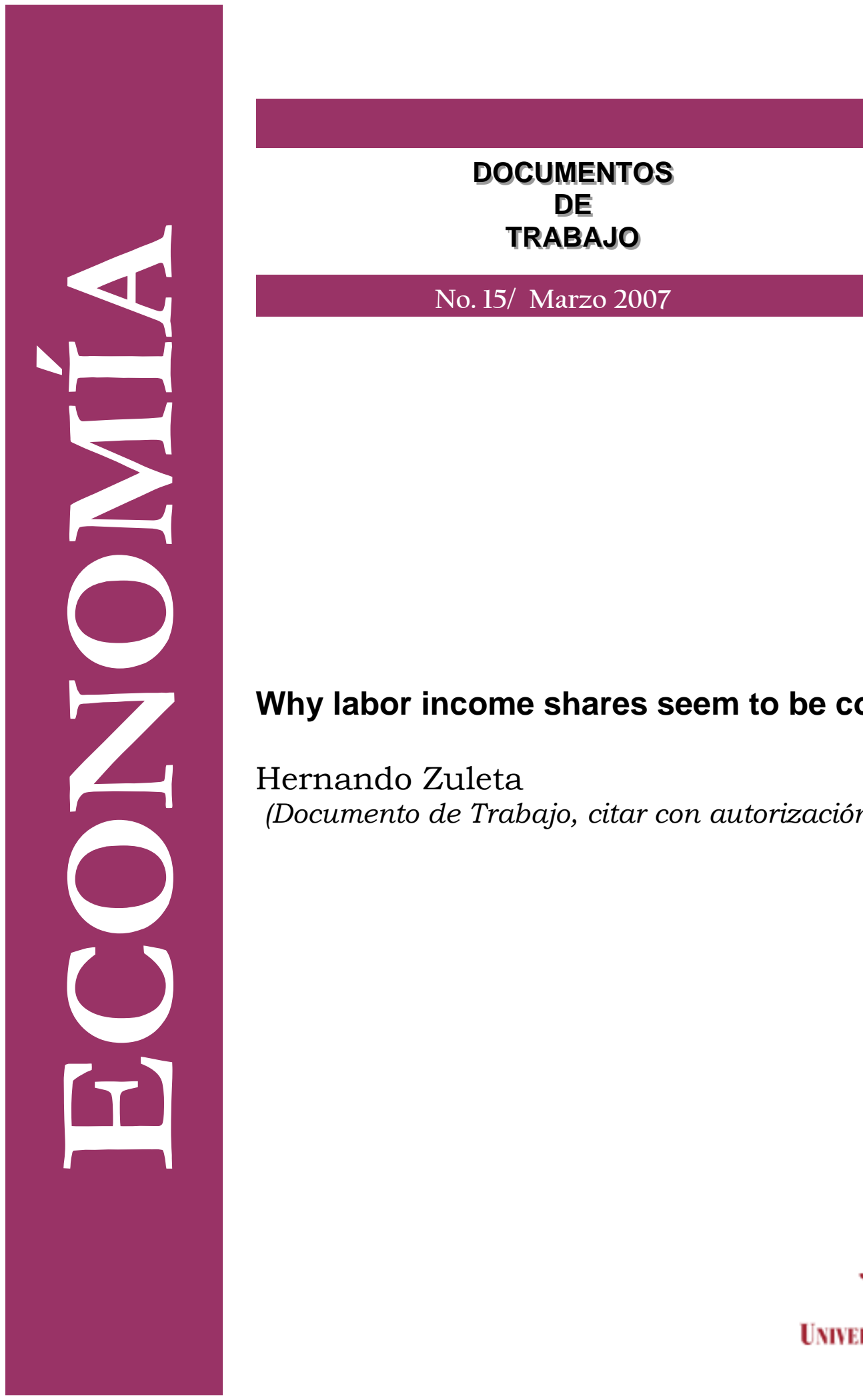

Why labor income shares seem to be constant?

Hernando Zuleta

(Documento de Trabajo, citar con autorización del autor)

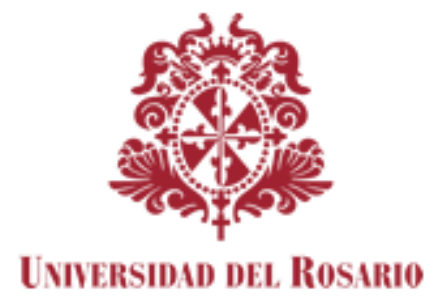




\title{
Why labor income shares seem to be constant?
}

\author{
Hernando Zuleta \\ Facultad de Economía Universidad del Rosario \\ e-mail: hernando.zuleta84@urosario.edu.co
}

Telephone: 57 (1) 2970200.

Address: Casa Pedro Fermín, Calle 14 \# 4 - 69, Bogotá Colombia.

- Las opiniones aquí expresadas son responsabilidad de los autores y por lo tanto no deben ser interpretadas como propias de la Facultad de Economía ni de la Universidad del Rosario 


\title{
Why labor income shares seem to be constant?
}

\begin{abstract}
The common assumptions that labor income share does not change over time or across countries and that factor income shares are equal to the elasticity of output with respect to factors have had important implications for economic theory. However, there are various theoretical reasons why the elasticity of output with respect to reproducible factors should be correlated with the stage of development. In particular, the behavior of international trade and capital flows and the existence of factor saving innovations imply such a correlation. If this correlation exists and if factor income shares are equal to the elasticity of output with respect to factors then the labor income share must be negatively correlated with the stage of development. We propose an explanation for why labor income share has no correlation with income per capita: the existence of a labor intensive sector which produces non tradable goods.
\end{abstract}

JEL classification: E1, F0, O0, O4.

Keywords: Factor Income Shares, Elasticity of output with respect to factors, two sector model. 


\section{Introduction}

The works by Cobb and Douglas (1928) and Kaldor (1961) created a paradigm for macroeconomics. The idea that labor income share does not decrease or increase with time or with economic growth ${ }^{1}$ had important implications in macroeconomics and growth theory. Considering an aggregate production function, if factor income shares are constant and the price of each factor is determined by its marginal productivity then the elasticity of output with respect to each factor is also constant. In other words the constancy of factor shares implies that the Cobb- Douglas is a good approximation for the aggregate production function.

Subscribing to this paradigm, almost all of the literature on economic growth accounting assumes that the elasticity of output with respect to capital (and labor) is constant and have concluded that the major part of economic growth is not explained by factor accumulation but by growth in TFP1 (see Easterly and Levine, 2002; Solow, 1957 or Young, 1994 among others). However there are 3 theoretical reasons why the elasticity of output with respect to reproducible factors, namely, physical capital and human capital, should be positively correlated with the stage of development:

1. International Trade. Eli Hecksher (1919) and Bertil Ohlin (1939) argue that comparative advantage arises from differences in national factor endowments. The Hecksher-Ohlin theory predicts that countries specialize and export those goods that make intensive use of

\footnotetext{
${ }^{1}$ The result was confirmed by Gollin (2002).
} 
locally abundant factors, while importing (producing less) goods that make intensive use of factors that are locally scarce. In other words, countries specialize in goods characterized by a high elasticity of output with respect to locally abundant factors. Therefore, international trade and specialization should increase the elasticity of aggregate output with respect to abundant factors and decrease the elasticity of aggregate output with respect to scarce factors. Finally, if factor income shares are equal to the elasticity of aggregate output with respect to factors then international trade and specialization should increase the ncome share of abundant factors and decrease the income share of scarce factors.

2. Foreign Direct Investment (FDI). According to John Dunning (1988) location-specific advantages can help explain the nature and direction of FDI. By location specific advantages, Dunning means the advantages that arise from using resource and factor endowments that are tied to a particular location. Therefore, firms producing laborintensive goods are likely to invest in labor abundant countries while firms producing capital-intensive goods are likely to invest in capital abundant countries. This implies that the behavior of FDI generates, in each country, an expansion in the sectors that use intensively abundant factors and, as a result, should increase the elasticity of aggregate output with respect to abundant factors and the income share of the abundant factors.

3. Factor Saving Innovations. Economic growth models of biased innovations have been proposed by Zeira (1998) and Zuleta (2003) among others. In these models factor scarcity generates incentives to invest in factor saving innovations, that is, people invest to reduce the need of scarce factors and increase the relative use of abundant factors. If factor prices are determined by marginal productivity of factors then laborsaving innovations reduce the 
income share of workers and increase capital income share.

If factor prices are determined by their marginal productivity and, consequently, the income share of each factor is identical to the elasticity of output with respect to such a factor, then the three theoretical arguments described above imply that the income share of reproducible factors should be positively correlated with the stage of development. So how can we explain the absence of a trend for capital income shares?

In economic growth, theorists are used to working with aggregate production functions. However, different sectors are likely to have different production functions and reveal different behaviors. In particular, consider a very labor intensive non-tradable sector where the possibilities of labor-saving innovations are low, namely, services, and suppose that this sector produces a normal good, X. The other sector produces the good Y, which is tradable and uses capital in a more intensive way. Under these circumstances, as an economy grows the demand for the good $\mathrm{X}$ also grows, which creates the need to hire more workers. As capital grows the cost of labor also increases, and so does the relative price of good X. If the effect of the increase in prices (in sector X) on labor demand is higher than the effect of the increase in capital, $\mathrm{Y}$, then, as the economy grows, more labor is allocated to the production of good X. Under such circumstances labor income share increases as the stock of capital grows. As it will become clear, this happens when the elasticity of substitution between goods $\mathrm{X}$ and $\mathrm{Y}$ is low enough. If this is the case, the question to ask is why capital income share does not decrease with the stage of development. Our claim is that the elasticity of output with respect to capital in sector $\mathrm{Y}$ is positively correlated with the stage of development. 
There are other models of economic growth that can explain why labor income share shares are not correlated with income. Zuleta (2003) points out that the standard measure of labor income includes raw labor income and human capital income and the standard measure of capital income includes land income and physical capital income. However, if one calculates the income share of reproducible factors (human and physical capital) it turns out that it is positively correlated with the income level (see Krueger, 1999, Hansen and Prescott, 2002 and Caselli and Feyrer, 2007). However, this approach cannot explain why the income share of human factors is relatively constant. ${ }^{2}$

\section{The Model}

Consider a two-sector model, where each sector produces a different good. Both goods X and $\mathrm{Y}$ are normal goods and their production functions are as follows:

$$
Y=K^{\alpha} L_{Y}^{1-\alpha} \quad X=B L_{X}
$$

where $\mathrm{K}$ is capital, $\mathrm{L}$ is labor, the sub-indexes $\mathrm{x}$ and $\mathrm{y}$ account for the amount of labor devoted to the production of goods $\mathrm{X}$ and $\mathrm{Y}$ respectively, $\mathrm{B}$ is the labor productivity in the production of good $\mathrm{X}, \alpha$ is the elasticity of output with respect to capital in the production of the good $Y$, and 1- $\alpha$ is the elasticity of output with respect to labor in the production of the good Y.

\footnotetext{
${ }^{2}$ We suggest a complementary explanation that can explain the trends of human factor shares within sectors (see Young, 2006). In particular, our model predicts a positive trend in the labor income share in the capital intensive (tradable) sector and a constant labor share in the labor intensive (non tradable) sector.
} 
For simplicity we assume constant labor supply and normalize $L=1$. Therefore, $L y=1-L x$. We also call $k$ the capital labor ratio in sector $\mathrm{Y}$ and use good $\mathrm{Y}$ as a numeraire. Markets are competitive so wage (w) is determined by the marginal productivity of labor, and the interest rate (r) is determined by the marginal productivity of capital, namely,

$$
w=(1-\alpha) k^{\alpha}=p B
$$

where $\mathrm{p}$ is the relative price of good $\mathrm{X}$.

Given that both goods are normal we can assume a CES utility function, $U=\left(C_{X}^{\phi}+C_{Y}^{\phi}\right)^{\frac{1}{\phi}}$, where Cy and Cx are the consumption of good $\mathrm{Y}$ and $\mathrm{X}$ respectively and the elasticity of substitution is given by $\varepsilon=1 /(1-\phi)$. Therefore, if the elasticity of substitution is positive, then $\phi \leq 1$, and if it is lower than one then $\phi \leq 0$.

Agents maximize utility so relative prices and consumption should relate in the following way:

$$
p=\left(\frac{C_{Y}}{C_{X}}\right)^{1-\phi}
$$

Therefore if the relative price of good $\mathrm{X}$ grows then consumers substitute consumption of good X for consumption of good Y. For simplicity we assume that total demand behaves in the same way that consumption does, that is, the demand for investment (I) of goods $\mathrm{X}$ and $\mathrm{Y}$ is such that $p=\left(I_{Y} / I_{X}\right)^{1-\phi}$. In this case, 


$$
p=\left(\frac{Y}{X}\right)^{1-\phi}=\left(\frac{K^{\alpha}\left(1-L_{X}\right)^{1-\alpha}}{B L_{X}}\right)^{1-\phi}
$$

Combining equations 4 and 2 we get:

$$
K=\left(\frac{B^{\phi}}{1-\alpha}\right)^{\frac{1}{\alpha \phi}}\left(1-L_{X}\right)^{\frac{1-\phi(1-\alpha)}{\alpha \phi}}\left(L_{X}\right)^{\frac{\phi-1}{\phi \alpha}}
$$

Therefore, if $\phi \leq 0$ or $\phi>\frac{1}{1-\alpha}$ then $\frac{\partial K}{\partial L_{X}}>0$. In other words, if the substitutability between $\mathrm{X}$ and $\mathrm{Y}$ is low enough, namely, $\varepsilon \leq 1$, then as the economy accumulates capital, the share of workers devoting their time to the production of good $\mathrm{X}$ grows3. Therefore for low elasticity of substitution between capital and labor there exists a positive relation between capital and share of labor in the production of good X.

Now, the labor income share of the economy (LISh) is given by the ratio between wage multiplied by the number of workers, $\mathrm{L}=1$, and total output $K^{\alpha} L_{Y}^{1-\alpha}+p B L_{X}$. Using equation 2 and rearranging,

$$
\operatorname{LISH}=\frac{1-\alpha}{1-\alpha L_{X}}
$$

From equation 6 it follows that if the elasticity of output with respect to capital in sector Y, $\alpha$, is constant then labor income share is positively correlated with the share of workers devoted to the production of the good X. Finally, from equations 5 and 6 it follows that, if $\varepsilon \leq 1$, then labor income share grows as $\mathrm{K}$ grows, that is, as the economies grow labor

\footnotetext{
${ }^{3}$ Estimates of Armington elasticities, that is, the elasticity of substitution between home and imported goods, have been supplied by a variety of scholars (see Blonigen and Wilson, 1999, for example). In these studies it is found that the Armington elasticities generally fall below 1.5. Given this result it is likely that the elasticity of substitution between tradable and non tradable goods is below 1.5 .
} 
income share grows.

In general, there exists a positive trend in the share of workers devoted to the production of services (see Table 1). Therefore, if the elasticity of output with respect to capital in sector $\mathrm{Y}$ is constant, then labor income share should have a positive trend. In other words, only if the elasticity of output with respect to capital in sector $\mathrm{Y}$ is positively correlated with the stage of development then aggregate labor income share can be constant.

[Insert table 1 about here]

\section{Conclusions}

The fields of International Trade, Foreign Direct Investment and Factor Saving Innovations provide different theoretical reasons why the elasticity of output with respect to reproducible factors should be positively correlated with the stage of development. Similarly, if factor prices are determined by factor marginal productivities then the elasticity of output with respect to factors determines factor income shares. This implies that there are 3 different theoretical reasons why the income share of reproducible factors should be positively correlated with the stage of development. In this paper we explain why labor income share can be constant even if factor prices are determined by factor marginal productivities and the elasticity of output with respect to reproducible factors increases with the stage of development. 
As an economy grows the demand for the goods produced by labor-intensive sector that is not subject to labor saving innovations also grows, which creates the need to hire more workers. As capital grows the cost of labor also increases, and so does the relative price of the labor intensive good. Therefore, as the economy grows, more labor is allocated to the production of the labor intensive good. Under such circumstances labor income share increases as the stock of capital grows. This result implies that only if the elasticity of output with respect to capital in sector $\mathrm{Y}$ is positively correlated with the stage of development then aggregate labor income share can be constant. 


\section{References}

Boldrin, M. and Levine, D. K. (2002) 'Factor Saving Innovations'. Journal of Economic Theory, 105 (1), 18-41.

Cobb, C. and Douglas, P.H. (1928) ‘A theory of Production’. American Economic Review, 18, 139-165

Blonigen, B. and W. Wilson (1999) 'Explaining Armington: What Determines

Substitutability between Home and Foreign Goods’. Canadian Journal of Economics, $32(1), 1-21$

Caselli, F. and Feyrer, J. (2007) 'The Marginal Product of Capital'. Quarterly Journal of Economics, forthcoming.

Dunning, John H. (1998) Explaining International Production London: Unwin Hyman.

Gollin, D. (2002) 'Getting Income Shares Right'. Journal of Political Economy, 110 (2), 458-474.

Hansen, G. and Prescott, E. (2002) 'From Malthus to Solow’ American Economic Review, 92 (4), 1205-1217.

Heckscher, Eli F. (1919) 'The Effect of Foreign Trade on the Distribution of Income’. Ekonomisk Tidskrif,. 497-512

Kaldor, N. (1961) 'Capital Accumulation and Economic Growth’ In FA Lutz and DC Hague (eds), The Theory of Capital. New York St, Martin’s Press, 177-222.

Krueger, A. (1999) ‘Measuring Labor's Share’. American Economic Review, 89 (2), 45-51. Ohlin, Bertil (1993) Interregional and International Trade. Cambridge: Harvard University Press.

Solow, R. (1957) 'Technical Change and the Aggregate Production Function'. Review of Economics and Statistics, 39, 312-320. 
Young, A. (1995) 'The Tyranny of Numbers: Confronting the Statistical Realities of the East Asian Growth Experience’. Quarterly Journal of Economics, 110: 641-680

Young, A. T. (2006) 'One of the Things We Know that Ain't So: Why US Labor's Share is not Relatively Stable’. Working Paper, University of Mississippi http://ssrn.com/abstract $=650783$

Zeira, J. (1998) 'Workers, Machines and Economic Growth'. Quarterly Journal of Economics, 113 (4), 1091-1118.

Zuleta, H. (2006) 'Factor Saving Innovations and Factor Income Shares’ Working Paper, Universidad del Rosario.

http://econpapers.repec.org/paper/col001070/002778.htm 


\section{Table 1}

Share of workers in services.

\begin{tabular}{|l|l|l|l|l|l|l|l|l|}
\hline & 1965 & 1970 & 1975 & 1980 & 1985 & 1990 & 1995 & 2000 \\
\hline Italy & 36.8 & 40.3 & 44.1 & 47.8 & 55.2 & 58.5 & 59.2 & 62.2 \\
\hline Spain & - & - & 39.7 & 44.9 & 50.1 & 54.9 & 61 & 62.3 \\
\hline Australia & 38 & 40.5 & 46.6 & 49.3 & 52.9 & 55.3 & 60.3 & 63.6 \\
\hline Japan & 44.7 & 46.9 & 51.5 & 54.2 & 56.4 & 58.7 & 60.7 & 63.7 \\
\hline Germany & 40.7 & 42.9 & 47.6 & 51 & 53 & 57.3 & 60.5 & 63.9 \\
\hline Finland & - & - & - & 51.8 & 56.5 & 60.7 & 64.5 & 66.3 \\
\hline Switzerland & 41.2 & 45.4 & - & 55 & 58.3 & 63.6 & 66.9 & 69.8 \\
\hline France & 43.1 & 47.2 & 51.1 & 55.5 & 60.8 & 64.6 & 69 & 72 \\
\hline Sweden & - & - & - & 62.1 & 66.1 & 67.8 & 71 & 72.9 \\
\hline Austria & 53.1 & 55 & 59.4 & 62.5 & 66.3 & 69.2 & 72.1 & 73.1 \\
\hline U. K. & 49.5 & 52 & - & 59.8 & 65.8 & 68.7 & 70.1 & 73.2 \\
\hline Norway & - & - & 56.1 & 61.6 & 65.4 & 68.8 & 71.4 & 73.8 \\
\hline Canada & - & 62.6 & 64.3 & 66.9 & 70.5 & 71.7 & 74 & 74.1 \\
\hline USA & - & 61.1 & 65.4 & 65.9 & 68.8 & 70.9 & 73.1 & 74.4 \\
\hline
\end{tabular}

